\title{
PREDISPOSING FACTORS TOWARDS EXAMINATION MALPRACTICE AMONG STUDENTS IN LAGOS UNIVERSITIES: IMPLICATIONS FOR COUNSELLING
}

\author{
BADEJO, A. O. PhD \\ Department of Educational Foundations and Counselling Psychology, \\ Faculty of Education, Lagos State University, Ojo \\ email: ayobadejo2001@yahoo.com
}

$\&$

GANDONU, M. B.

Department of Psychology, Faculty of Social Sciences,

Lagos State University, Ojo.

\begin{abstract}
The study attempted to examine students' perception of the predisposing factors towards examination malpractice among students in Lagos universities. The study adopted the descriptive survey design involving 240 students from the Faculty of Education in the two public universities in Lagos State. A questionnaire on the predisposing factors towards examination malpractice (PFTEMQ) was developed by the researchers to source for data. One research question was raised and two hypotheses were generated for the study and tested at 0.05 level of significance. Findings revealed that students, academic staff and the university authorities were contributory factors in the incidence of examination malpractice; also, gender and age are no indices for examination malpractice among students. In view of this, the implications for counselling were highlighted.
\end{abstract}

Key Words: Predisposing Factors, Examination Malpractice, University Students, Counselling, Perception

\section{Introduction}

Education is the key to development in any nation and Nigeria is no exception. This has led to a quest to acquire education by all means as employers of labour place emphasis on certificates especially that of the university before one can be given any reasonable position in any organization. 
Predisposing factors towards examination malpractice among students

in Lagos universities: Implications for counselling

Badejo, A. 0. \& Gandonu, II. B

The main objective of university education is to train students to acquire the requisite knowledge and skills to enable them to contribute effectively to national development(National Policy on Education, 2004).This training requires periodic assessment and evaluation in form of examinations to ascertain the level of competence of students. Although examinations are not the only instruments for assessing students' knowledge in the university, they have emerged as the major established yardstick and the most practical way of assessment. This has led to students devising different types of methods to pass examinations at all cost; thereby resulting in examination malpractice. Some of these methods are impersonation, exchange of answer scripts by students, writing relevant information on parts of the body and pieces of paper etc (Anan, 2005).

Examination malpractice can be defined as 'a deliberate act of wrong doing, contrary to official rules, and is designed to place a candidate at an unfair advantage or disadvantage; it is a careless, illegal or unacceptable behaviour by a candidate in a formal test of his knowledge or ability in a particular subject (Philemon, 2007). It could also be said to be an act of omission or commission which compromises the validity and integrity of any examination (Okwu, 2006). Examination malpractice is counter-practice that is against ethics of examination, it is an act of disrespect to all rules and regulations guiding the good conduct of any examination or any evaluation process.

Examination malpractice has assumed a frightening proportion in Nigeria. This therefore should be a concern to stakeholders in education. Hence, this study seeks to examine the predisposing factors towards examination malpractice among students in Lagos universities and its implications for counselling.

One research question and two hypotheses guided the study.

\section{Research Question}

What is the perception of students as regards the predisposing factors towards examination malpractice among students in Lagos Universities?

\section{Research Hypotheses}

(i) There is no significant gender difference in students' perception of the predisposing factors towards examination malpractice among students in Lagos universities. 
(ii) There is no significant age difference in students' perception of the predisposing factors towards examination malpractice among students in Lagos universities.

\section{Methodology}

Research Design

A descriptive survey was adopted for the study as it aimed at determining the situation of the problem at the period of the study.

\section{Population and Sample}

The study was carried out among students in the Faculty of Education in Lagos State University and students in the Faculty of Education in University of Lagos. Only the second and the third year students were selected as sample as the first year students were new in the faculty and the fourth year students were busy preparing for their examinations. Students in the Faculty of Education were used for the study as they will be the ones to go and teach children in the primary and secondary schools and it is expected that they instil a positive approach to examination in their wards.

240 students from 200-level and 300-level were randomly selected from the population. This comprised of 60 males and 60 females from each University (i.e. 30 males and 30 females from each level of the population.

\section{Research Instrument}

The researchers developed an instrument tagged Predisposing Factors towards Examination Malpractice Questionnaire (PFTEMQ) which was used for the study. It consisted of four sections. Section A contained personal data of the respondents while the other three sections consisted of items on the study variables. Sections B, C and D which contain 8 items each centre on problems posed by the University Authorities, Lecturers and students respectively. The response format of PFTEMQ is of a 4point rating scale: strongly agree (SA), agree (A), disagree (D), and strongly disagree (SD).

The instrument was presented to two experts in counselling psychology for face validity. For reliability, the test-retest method was used with a two-week interval between the two tests. The Pearson Product Moment Correlation Coefficient was used and the score yielded 0.87 which was considered good for the study. 
Predisposing factors towards examination malpractice among students

in Lagos universities: Implications for counselling

Badejo, A. 0. \& Gandonu, II. B

\section{Data Analysis}

For research question 1, data was analysed using percentages; for hypothesis 1, the t-test was used while for hypothesis 2, ANOVA was used.

Research Question 1

What is the perception of students as regards the predisposing factors towards examination malpractice among Lagos universities students?

Table 1: Table of Percentages on Students' Perception of the Predisposing factors towards Examination Malpractice

Problems Posed by the University Authorities

\begin{tabular}{|l|l|c|c|c|c|c|}
\hline S/N & \multicolumn{1}{|c|}{ Items } & $\begin{array}{c}\text { Strongly } \\
\text { Agree }\end{array}$ & Agree & Disagree & $\begin{array}{c}\text { Strongly } \\
\text { Disagree }\end{array}$ & $\begin{array}{c}\text { Total } \\
\%\end{array}$ \\
\hline 1. & $\begin{array}{l}\text { Unstable } \\
\text { school } \\
\text { calendar can } \\
\text { lead to } \\
\text { examination } \\
\text { malpractice }\end{array}$ & $150(62.5)$ & $50(20.8)$ & $10(4.2)$ & $30(12.5)$ & 100 \\
\hline 2. & $\begin{array}{l}\text { Inadequate } \\
\text { notice of can } \\
\text { lead to exam } \\
\text { malpractice }\end{array}$ & $40(16.6)$ & $190(79.2)$ & 0 & $10(4.2)$ & 100 \\
\hline 3. & $\begin{array}{l}\text { Improper } \\
\text { structure of } \\
\text { exam time } \\
\text { table can } \\
\text { encourage } \\
\text { cheating } \\
\text { during exams }\end{array}$ & $90(37.5)$ & $120(50)$ & $10(4.2)$ & $20(8.3)$ & 100 \\
\hline 4. & $\begin{array}{l}\text { Inadequate } \\
\text { facilities for } \\
\text { exams can } \\
\text { encourage } \\
\text { students to } \\
\text { cheat }\end{array}$ & $60(25)$ & $145(60.4)$ & $5(2.1)$ & $30(12.5)$ & 100 \\
\hline
\end{tabular}




\begin{tabular}{|l|l|c|c|c|c|c|}
\hline S/N & \multicolumn{1}{|c|}{ Items } & $\begin{array}{c}\text { Strongly } \\
\text { Agree }\end{array}$ & Agree & Disagree & $\begin{array}{c}\text { Strongly } \\
\text { Disagree }\end{array}$ & $\begin{array}{c}\text { Total } \\
\%\end{array}$ \\
\hline 5. & $\begin{array}{l}\text { Collaboration } \\
\text { between staff } \\
\text { and students } \\
\text { brings about } \\
\text { exam } \\
\text { malpractice }\end{array}$ & $200(83.3)$ & $30(12.5)$ & 0 & $10(4.2)$ & 100 \\
\hline 6. & $\begin{array}{l}\text { Much focus } \\
\text { on cognitive } \\
\text { assessment } \\
\text { brings about } \\
\text { exam } \\
\text { malpractice }\end{array}$ & $200(83.3)$ & $35(14.6)$ & 0 & $5(2.1)$ & 100 \\
\hline 7. & $\begin{array}{l}\text { Inadequate } \\
\text { monitoring of } \\
\text { lecturers } \\
\text { activities can } \\
\text { bring about } \\
\text { exam } \\
\text { malpractice }\end{array}$ & $70(29.2)$ & $120(50)$ & $20(8.3)$ & $30(12.5)$ & 100 \\
\hline 8. & $\begin{array}{l}\text { Inadequate } \\
\text { concern to } \\
\text { students } \\
\text { welfare } \\
\text { promote exam } \\
\text { malpractice }\end{array}$ & $50(20.8)$ & $100(41.7)$ & $20(8.3)$ & $70(29.2)$ & 100 \\
\hline
\end{tabular}

\section{Problems Posed by Lecturers}

\begin{tabular}{|l|l|c|c|c|c|c|}
\hline S/N & Items & $\begin{array}{c}\text { Strongly } \\
\text { Agree }\end{array}$ & Agree & Disagree & $\begin{array}{c}\text { Strongly } \\
\text { Disagree }\end{array}$ & $\begin{array}{c}\text { Total } \\
\%\end{array}$ \\
\hline 1. & $\begin{array}{l}\text { Poor } \\
\text { attendance of } \\
\text { lecturers in } \\
\text { class } \\
\text { encourages } \\
\text { students to } \\
\text { cheat in } \\
\text { exams }\end{array}$ & $200(83.3)$ & $30(12.5)$ & $5(2.1)$ & $5(2.1)$ & 100 \\
\hline
\end{tabular}


Predisposing factors towards examination malpractice among students

in Lagos universities: Implications for counselling

Badejo, A. 0. \& Gandonu, II. B

\begin{tabular}{|c|c|c|c|c|c|c|}
\hline $\mathrm{S} / \mathrm{N}$ & Items & $\begin{array}{c}\text { Strongly } \\
\text { Agree }\end{array}$ & Agree & Disagree & $\begin{array}{l}\text { Strongly } \\
\text { Disagree }\end{array}$ & $\begin{array}{c}\text { Total } \\
\%\end{array}$ \\
\hline 2. & $\begin{array}{l}\text { High- } \\
\text { handedness of } \\
\text { some lecturers } \\
\text { influences } \\
\text { students' } \\
\text { involvement } \\
\text { in exam } \\
\text { malpractices }\end{array}$ & $100(41.7)$ & $80(33.5)$ & $5(2.1)$ & $5(2.1)$ & 100 \\
\hline 3. & $\begin{array}{l}\text { Use of poor } \\
\text { lecture } \\
\text { methods } \\
\text { facilitates } \\
\text { exam } \\
\text { malpractices }\end{array}$ & $50(20.8)$ & 180(75) & 0 & $10(4.2)$ & 100 \\
\hline 4. & $\begin{array}{l}\text { Frequent } \\
\text { strike actions } \\
\text { encourages } \\
\text { exam } \\
\text { malpractices }\end{array}$ & $110(45.8)$ & $100(41.7)$ & $5(2.1)$ & $5(2.1)$ & 100 \\
\hline 5. & $\begin{array}{l}\text { Inadequate } \\
\text { teacher-pupil } \\
\text { interaction in } \\
\text { class can } \\
\text { encourage } \\
\text { exam } \\
\text { malpractices }\end{array}$ & $40(16.6)$ & $100(41.7)$ & $20(8.3)$ & $80(33.3)$ & 100 \\
\hline 6. & $\begin{array}{l}\text { Sexual } \\
\text { harassment } \\
\text { from lecturers } \\
\text { can encourage } \\
\text { students to } \\
\text { cheat in } \\
\text { exams }\end{array}$ & $75(20.8)$ & $150(62.5)$ & $0(0.0)$ & $40(16.1)$ & 100 \\
\hline
\end{tabular}




\begin{tabular}{|l|l|c|c|c|c|c|}
\hline S/N & Items & $\begin{array}{c}\text { Strongly } \\
\text { Agree }\end{array}$ & Agree & Disagree & $\begin{array}{c}\text { Strongly } \\
\text { Disagree }\end{array}$ & $\begin{array}{c}\text { Total } \\
\%\end{array}$ \\
\hline 7. & $\begin{array}{l}\text { Using } \\
\text { students to } \\
\text { mark } \\
\text { examination } \\
\text { scripts } \\
\text { encourages } \\
\text { exam } \\
\text { malpractices }\end{array}$ & $70(29.2)$ & $150(62.5)$ & $0(0.0)$ & $20(8.3)$ & 100 \\
\hline 8. & $\begin{array}{l}\text { Extortion of } \\
\text { students by } \\
\text { lecturers } \\
\text { promotes } \\
\text { exam } \\
\text { malpractice }\end{array}$ & $100(41.7)$ & $100(41.7)$ & $0(0.0)$ & $40(16.6)$ & 100 \\
\hline
\end{tabular}

Problems Posed by Students

\begin{tabular}{|l|l|c|c|c|c|c|}
\hline S/N & Items & $\begin{array}{c}\text { Strongly } \\
\text { Agree }\end{array}$ & Agree & Disagree & $\begin{array}{l}\text { Strongly } \\
\text { Disagree }\end{array}$ & $\%$ \\
\hline 1. & $\begin{array}{l}\text { Poor attendance } \\
\text { at lectures by } \\
\text { students } \\
\text { encourages } \\
\text { exam } \\
\text { malpractice }\end{array}$ & $190(79.2)$ & $40(16.6)$ & $0(0.0)$ & $10(4.2)$ & 100 \\
\hline 2. & $\begin{array}{l}\text { Inadequate } \\
\text { preparation for } \\
\text { exams makes } \\
\text { students cheat } \\
\text { in exams }\end{array}$ & $50(20.8)$ & $160(60.7)$ & $0(0.0)$ & $30(12.5)$ & 100 \\
\hline 3. & $\begin{array}{l}\text { Inability to get } \\
\text { reading } \\
\text { materials } \\
\text { facilitates exam } \\
\text { malpractice }\end{array}$ & $20(8.3)$ & $150(62.5)$ & $0(0.0)$ & $70(29.2)$ & 100 \\
\hline 4. & $\begin{array}{l}\text { Lack of } \\
\text { confidence } \\
\text { promotes exam } \\
\text { malpractice }\end{array}$ & $170(70.8)$ & $60(25.0)$ & $0(0.0)$ & $10(4.2)$ & 100 \\
\hline
\end{tabular}


Predisposing factors towards examination malpractice among students

in Lagos universities: Implications for counselling

Badejo, A. 0. \& Gandonu, I. B

\begin{tabular}{|l|l|c|c|c|c|c|}
\hline S/N & Items & $\begin{array}{c}\text { Strongly } \\
\text { Agree }\end{array}$ & Agree & Disagree & $\begin{array}{c}\text { Strongly } \\
\text { Disagree }\end{array}$ & $\mathbf{\%}$ \\
\hline 5. & $\begin{array}{l}\text { Laziness } \\
\text { promotes exam } \\
\text { malpractice }\end{array}$ & $200(83.3)$ & $40(16.7)$ & $0(0.0)$ & $0(0.0)$ & 100 \\
\hline 6. & $\begin{array}{l}\text { Mad-rush for } \\
\text { certificate } \\
\text { encourages } \\
\text { students to } \\
\text { cheat in exams }\end{array}$ & $210(87.5)$ & $20(8.3)$ & $0(0.0)$ & $10(4.2)$ & 100 \\
\hline 7. & $\begin{array}{l}\text { Negative peer } \\
\text { influence brings } \\
\text { about exam } \\
\text { malpractice }\end{array}$ & $190(79.2)$ & $50(20.8)$ & $0(0.0)$ & $0(0.0)$ & 100 \\
\hline 8. & $\begin{array}{l}\text { Too much } \\
\text { involvement in } \\
\text { social activities } \\
\text { promotes exam } \\
\text { malpractice }\end{array}$ & $20(8.3)$ & $180(75.0)$ & $0(0.0)$ & $40(16.7)$ & 100 \\
\hline
\end{tabular}

In Table 1, the percentage of students' responses towards problems posed by the university authorities revealed that focusing examinations more on the cognitive, which often is based on recall of facts, encourage students to get involved in examination malpractices. The students' view on lecturers and the students respectively on predisposing factors towards examination malpractices also revealed that lecturers attendance in class, coupled with laziness of the students promote examination malpractice.

\section{Hypothesis 1}

There is no significant gender difference in students' perception of the predisposing factors towards examination malpractice among students in Lagos universities. 
Table 2: t-test table on Gender Differences on Students' Perception of Predisposing factors towards Examination Malpractice

\begin{tabular}{|l|c|c|c|c|c|}
\hline \multicolumn{1}{|c|}{ Gender } & Mean & SD & df & t-cal & t-crit \\
\hline $\begin{array}{l}\text { Male (120) } \\
\text { Female } \\
(120)\end{array}$ & 18.83 & 65.29 & & & \\
\hline
\end{tabular}
n.s $=$ not significant at 0.05 level

Table 2 shows a calculated $t-$ value of 0.0593 which is less than the $t-$ critical of 1.96 at 0.05 level of significance. This therefore means that there is no significant gender difference in students' perception of predisposing factors towards examination malpractice in Lagos universities. In other words, both male and female students perceived factors which could lead to examination malpractices the same way.

\section{Hypothesis 2}

There is no significant age difference in students' perception of the predisposing factors towards examination malpractice among students in Lagos universities.

Table 3: ANOVA of Age Differences in Students' Perception of the Predisposing factors towards Examination Malpractice

\begin{tabular}{|l|c|c|c|c|c|}
\hline Variations & $\begin{array}{c}\text { Sum of } \\
\text { Squares }\end{array}$ & $\begin{array}{c}\text { Mean of } \\
\text { Squares }\end{array}$ & df & f-cal & f-table \\
\hline Between & 1734375 & 34687.5 & $\mathrm{k}-1$ & & \\
Group & & & 5 & & \\
Within & 3884194 & 16599.12 & $\mathrm{n}-\mathrm{k}$ & 2.09 & $\mathrm{n} . \mathrm{s}$ \\
Group & & & 234 & & 2.214 \\
Total & 4057631.5 & & 239 & & \\
\hline
\end{tabular}

n.s $=$ not significant at 0.05 level

Table 3 above shows that the calculated $f$ value of 2.09 is less than the critical value of 2.14 with 5/239 degrees of freedom at 0.05 level of significance. Therefore the hypothesis is accepted. This means that there is no significant age difference in students' perception of the predisposing factors towards examination malpractice. That means no matter the age range, students' behaviours towards examination malpractices are same. 
Predisposing factors towards examination malpractice among students

in Lagos universities: Implications for counselling

Badejo, A. 0. \& Gandonu, I. B

\section{Discussion}

From the analysis of data above, $83.3 \%$ of the respondents strongly agreed that collaboration between staff and students can lead to examination malpractice. Also, 83.3\% agreed that poor attendance of lecturers in class can encourage students to cheat in examinations while $62.5 \%$ of the respondents also agreed that high- handedness of some lecturers' influences students' involvement in examination malpractice. This means that lecturers are a contributory factor in examination malpractice issues. Furthermore, $79.2 \%$ of the respondents agreed that poor attendance of students at lectures can lead to examination malpractice. $87.5 \%$ also agreed that the mad rush for certificates encourages students to cheat in examinations. The foregoing therefore establishes that university authorities, academic staff and students are all contributory factors in the issue of examination malpractice.

The result of hypothesis 1 shows that there is no significant gender difference in students' perception of the predisposing factors towards examination malpractice in Lagos universities. This implies that examination malpractice is not a function of gender; rather, both male and female students have the tendency to be involved in examination malpractice. This finding agrees with that of Olatoye (2002) whose study revealed that examination malpractice is a general phenomenon among male and female students. This means that both male and female students have equal chance in being involved in examination malpractices.

The result of hypothesis 2 shows that there is no significant age difference in the perception of students as regards the predisposing factors towards examination malpractice among students in Lagos universities. This means that age is not a factor in the perception of Lagos universities undergraduates as to the predisposing factors towards examination malpractice. That is, regardless of age range, the perception of Lagos university students does not differ. This finding corroborates that of Oduwaiye (2003) whose study revealed that there is no specific age range of students who engage in examination malpractice. She is of the opinion that examination malpractice occurs at all levels of education be it primary, secondary or tertiary. This also denotes that both male and female students have equal perception towards examination malpractices. The researchers therefore opined that regardless of age and level of education of students in Lagos universities, their perception on predisposing factors towards examination malpractices remain the same. 


\section{Implications for Counselling}

The study revealed that examination malpractice is traceable not only to student factors but also those of lecturers and the universities authorities. Hence, counsellors in the university setting should not only focus attention on the students alone but also on the academic staff and school authority.

Counselling centres in universities should be involved in the students' admission process. At the point of entry, it is expected that the university counselling centre endeavours to let incoming students understand their obligations to respect and obey constituted authority. In this regard, the students should be acquainted with the Information Handbook and of Code of Conduct Manual relating to the do's and don'ts on the campus. They should be provided with information on issues like:

- general behaviour on the campus,

- procedures for continuous assessment of courses,

- lecture attendance and eligibility for examinations,

- use of university facilities such as library, counselling centre, recreational facilities.

Concerning academic staff, counsellors through periodic seminars and workshops should motivate the academic staff to engage in research and meaningful community service (Okwu, 2006) as no education system can rise above the quality of its teachers. Hence, good quality and meaningful teaching is expected of them. Furthermore, members of academic staff are expected to attend lectures punctually and be wellprepared, be accessible to students, give and grade tests and assignments objectively, provide prompt feedback to students on their performance and avoid taking undue advantage of students.

The basic obligation of the university administration is the provision of conducive working and learning environment for staff and students. This includes:

- formulation of concrete and achievable goals,

- provision of necessary human, material and arid fiscal resources to work with,

- provision and application of a fair and free policy framework for dealing with non-compliance to set standards. 
Predisposing factors towards examination malpractice among students

in Lagos universities: Implications for counselling

Badejo, A. 0. \& Gandonu, II. B

\section{Recommendations}

- Moral counselling with the use of Rational Emotive Behaviour Therapy and other related theories should be used as a strategy to reduce involvement of students and staff in examination malpractice

- Adequate number of invigilators should be assigned to examination rooms

- All activities relating to examinations such as question paper production, invigilation marking, result collation and computation should be handled with a high level of responsibility by those concerned.

- Lastly, concerted efforts should be made to properly acquaint staff and students with regulations governing examination conduct in the university.

\section{References}

Adomako, A. K. (2005): Examination Malpractices: University? Shame, Students? Burden. Retrieved from http://ghanaHomepage/ / features/artikle on $14^{\text {th }}$ Oct., 2008

Ajibola, O. (2008): Advocates of Examination Malpractice. Retrieved from http:/ / ezinearticles.com on $15^{\text {th }}$ Oct., 2008

Annan, R. (2005). Dangers of Examination Malpractices. Retrieved from http://ghanaweb.com/GhanaHomePage//feature/artikle on $14^{\text {th }}$ Oct., 2008

Daily Trust, Abuja (2008) Nigeria: The Monster Called Examination Malpractices. Retrieved from http://www.newswatchngr.com on 15th Oct., 2008

Ejembi, R. (2007). How to Curb Examination Malpractices. Retrieved from http:// www.sunnewsonline.com on $14^{\text {th }}$ Oct., 2008

Federal Ministry of Education (2004). National Policy on Education. Abuja: Federal Ministry of Education Publication.

Oduwaiye, R. O. (2005). Students' Perception of Factors and Solution to Examination Malpractices in Nigerian Universities: A Case Study of the University of Ilorin. Retrieved from http://www.ilorin.edu.ng/ unilorin/journal/education on $16^{\text {th }}$ Oct., 2008

Okecha, S. A. (2008). How to Fix Nigeria: Education. Retrieved from http:// www.newswatchngr.com on $15^{\text {th }}$ Oct., 2008 
Okwu, O. J. (2006). A Critique of Students' Vices and the Effect on Quality of Graduates of Nigeria Tertiary Institutions. Retrieved from http://www.krepublishers.com/02- journal on 16 ${ }^{\text {th }}$ Oct., 2008

Olatoye, R. A. (2000). Checking the Menace of Examination Malpractice: A call for more Teaching and Learning in schools. Retrieved from http://www.naere.org/journal/Volume 5, No.1, 2004 on 15 th Oct., 2008

Philemon, A. O. (2007). The Menace called Examination Malpractice in Nigeria. Retrieved from http://meaningfulquota.bloghi.com on $14^{\text {th }}$ Oct., 2008

Taiwo, J. (2003). Nigeria Loses N1bn to Examination Malpractice-Group. Retrieved from http://www.naijapost.com on 14th Oct., 2008. 